\title{
Involvement of the bone morphogenetic protein system in endothelin- and aldosterone-induced cell proliferation of pulmonary arterial smooth muscle cells isolated from human patients with pulmonary arterial hypertension
}

\author{
Ryutaro Yamanaka $^{1}$, Fumio Otsuka ${ }^{1}$, Kazufumi Nakamura $^{2}$, Misuzu Yamashita $^{1}$, Hiroyuki Otani ${ }^{1}$, \\ Masaya Takeda ${ }^{1}$, Yoshinori Matsumoto ${ }^{1}$, Kengo F Kusano ${ }^{2}$, Hiroshi Ito $^{2}$ and Hirofumi Makino ${ }^{1}$
}

Recent genetic studies have uncovered a link between familial and idiopathic pulmonary arterial hypertension (PAH) and germline mutations in the bone morphogenetic protein type-II receptor (BMPRII). The pathology of PAH is characterized by remodeling of the pulmonary arteries due to pulmonary artery smooth muscle cell (PASMC) hyperproliferation. Although increased endothelial injury and impaired suppression of PASMC proliferation are both critical for the cellular pathogenesis of PAH, a detailed molecular mechanism underlying PAH has yet to be elucidated. In the present study, we investigated the roles of the BMP system and other vasoactive factors associated with PAH (including endothelin (ET), angiotensin II (Ang II) and aldosterone) in the mitotic actions of PASMCs isolated from idiopathic and secondary PAH lungs. ET1 and aldosterone stimulated PASMC proliferation of idiopathic PAH more effectively than secondary PAH, whereas Ang II and ET3 failed to activate mitosis in either of the PASMC cell type. The effects of ET1 and aldosterone were blocked by bosentan, an ET type-A/B receptor (ETA/BR) antagonist, and eplerenone, a selective mineralocorticoid receptor (MR) blocker, respectively. Among the BMP ligands examined, BMP-2 and BMP-7, but not BMP-4 or BMP-6, significantly increased cell mitosis in both PASMC cell types. Notably, ET1- and aldosterone-induced mitosis and mitogen-activated protein kinase phosphorylation were significantly increased in the presence of BMP-2 and BMP-7 in PASMCs isolated from idiopathic PAH, although additive effects were not observed in PASMCs isolated from secondary PAH. Inhibition of extracellular signal-regulated kinase 1 (ERK1)/ERK2 signaling suppressed basal-, ET1- and aldosterone-induced PASMC mitosis more potently than that of stress-activated protein kinase/c-Jun NH2-terminal kinase inhibition. Given the fact

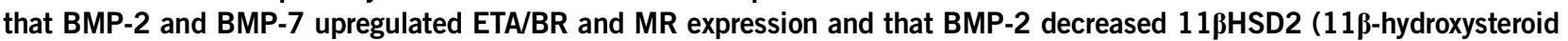
dehydrogenase type 2) levels in PASMCs isolated from idiopathic PAH, BMPR-Smad signaling may have a key role in amplifying the ETA/BR and/or MR-ERK signaling in PASMCs of the PAH lung. Collectively, the functional link between BMP and ET and/or the MR system may be involved in the progress of PASMC mitosis, ultimately leading to the development of clinical PAH. Hypertension Research (2010) 33, 435-445; doi:10.1038/hr.2010.16; published online 26 February 2010

Keywords: aldosterone; bone morphogenetic protein; endothelin; mineralocorticoid receptor; pulmonary arterial hypertension

\section{INTRODUCTION}

Pulmonary arterial hypertension $(\mathrm{PAH})$ is a life-threatening disease that has a prevalence of one to two patients per one million individuals, with a higher frequency in women. ${ }^{1}$ This disease is histologically characterized by excessive proliferation of vascular endothelium and smooth muscle cells, causing thickening of pulmonary arteriole walls and formation of plexiform lesions that eventually occlude the vascular lumen. ${ }^{2}$ The remodeling of pulmonary arterioles increases vascular resistance and reduces vascular dilatation, resulting in right ventricular failure.

Approximately six percent of PAH cases have an autosomal-dominant pattern of inheritance. Recent research has uncovered a genetic predisposition to familial PAH. ${ }^{3,4}$ Two studies involving the screening of the locus of the gene for PAH have mapped it to chromosome $2 \mathrm{q} 33$ (PPH1) and found mutations in the BMPR2 gene, which encodes bone morphogenetic protein type-II receptor (BMPRII), in 9 out of

${ }^{1}$ Department of Medicine and Clinical Science, Okayama University Graduate School of Medicine, Dentistry and Pharmaceutical Sciences, Okayama, Japan and ${ }^{2}$ Department of Cardiovascular Medicine, Okayama University Graduate School of Medicine, Dentistry and Pharmaceutical Sciences, Okayama, Japan

Correspondence: Dr F Otsuka, Department of Medicine and Clinical Science, Okayama University Graduate School of Medicine, Dentistry and Pharmaceutical Sciences, 2-5-1 Shikata-cho, Kitaku, Okayama 700-8558, Japan.

E-mail: fumiotsu@md.okayama-u.ac.jp

Received 14 October 2009; revised and accepted 5 January 2010; published online 26 February 2010 
$19^{5}$ or 7 out of 8 families. ${ }^{6}$ Furthermore, the BMPR2 mutation can be detected in at least one quarter of sporadic PAH cases. ${ }^{7}$

Hence, the identification of heterozygous germline mutations in the BMPR2 gene in familiar and sporadic cases of PAH has proven to be a crucial breakthrough in elucidating the underlying pathogenesis of PAH. ${ }^{3}$ Subsequent functional studies have provided compelling evidence that PAH cells that harbor the BMPR2 mutations exhibit aberrant BMPRII function and disrupted BMP signaling. ${ }^{8,9}$ However, given the fact that almost half of all $\mathrm{PAH}$ patients do not have the BMPR2 mutation, the entire mechanism of pulmonary artery smooth muscle cell (PASMC) mitogenesis in PAH lungs is still unclear. BMP ligands that are involved in the aberrant signaling caused by the BMPRII mutations in PAH patients have also not been identified.

Pulmonary vascular wall thickening due to inappropriate proliferation of PASMCs is a central cause of elevated pulmonary vascular resistance and arterial pressure in PAH patients. ${ }^{10,11}$ Unbalanced proliferation and apoptosis of smooth muscle cells contributes to vascular remodeling in pulmonary hypertension. ${ }^{12}$ Disequilibrium in vasoactive mediators in the lungs, including increased thromboxane and endothelin-1 (ET1) and decreased prostacyclin and nitric oxide, leads to vasoconstriction and proliferation of smooth muscle cells. ${ }^{13,14}$ Studies using various ET receptor antagonists have confirmed that ET1 is a critical factor in the pathogenesis of vascular remodeling in experimental models of chronic pulmonary hypertension and clinical observation of pulmonary hypertension. ${ }^{15,16}$ In addition to the role of ET1 as a potent vasoconstrictor, it also acts directly to modulate the growth of human pulmonary vascular smooth muscle cells as an autocrine/paracrine mitogen. ${ }^{17,18}$

Additional factors, such as serotonin, platelet-derived growth factor (PDGF) and angiotensins, have been postulated to contribute to pulmonary vasoconstriction, increased smooth muscle growth and increased matrix deposition. A polymorphism in the angiotensinconverting enzyme gene is known to be associated with the manifestation of pulmonary hypertension. ${ }^{19}$ Increased angiotensin-converting enzyme expression is observed in plexiform lesions in $\mathrm{PAH},{ }^{20}$ and angiotensin-converting enzyme inhibition seems to delay pulmonary vascular neointimal formation. ${ }^{21}$ Therefore, the renin-angiotensinaldosterone system (RAAS) represents a group of candidate genes that could modify disease severity and/or age at diagnosis of individuals predisposed to develop PAH. Angiotensin II (Ang II) binds primarily to the Ang II type-1 receptor (AT1R) to promote vascular smooth muscle constriction. Genetic variants or polymorphisms in genes within AT1R are known to enhance RAAS activation and/or receptor function, which may be linked to modifications in the risk of developing PAH. ${ }^{22}$ Ang II also acts on the adrenal cortex to promote aldosterone production by CYP11B2, which encodes $\mathrm{P} 450$ aldosterone synthase. However, the significance of aldosterone action in the pathogenesis of PAH has yet to be elucidated. There is also accumulating evidence indicating that aldosterone exerts physiologically and/ or pathophysiologically relevant effects on the cardiovascular system, kidney and brain, in addition to its well-established role in regulating body electrolytes and water homeostasis.

In the present study, we attempted to elucidate the underlying mechanism of abnormal PASMC proliferation and the functional link between the BMP system and other vasoactive factors for PAH, including ET, Ang II and aldosterone, in the mitotic actions of PASMCs isolated from primary and secondary PAH lungs.

\section{METHODS}

\section{Reagents and supplies}

Dulbecco's modified Eagle's medium, penicillin-streptomycin solution, angiotensin II acetate salt (Ang II), d-aldosterone, dimethylsulfoxide (DMSO) and human ET1 and ET3 were purchased from Sigma-Aldrich (St. Louis, MO, USA). Recombinant human BMP-2, BMP-4, BMP-6 and BMP-7 and mouse noggin were purchased from R\&D Systems (Minneapolis, MN, USA) and human PDGF-BB was from PeproTech EC (London, UK). U0126 and SB203580 were purchased from Promega (Madison, WI, USA) and SP600125 was purchased from Biomol Lab (Plymouth Meeting, PA, USA). Bosentan, candesartan (CV-11974) and eplerenone were kindly provided by Actelion Pharmaceuticals (Allschwil, Switzerland), Takeda Chemical Industries (Osaka, Japan) and Pfizer (New York, NY, USA), respectively.

\section{Isolation of human PASMCs and establishment of primary PASMC culture}

Human PASMCs were isolated during lung transplant surgery from patients diagnosed with idiopathic pulmonary arterial hypertension (PAH) and secondary pulmonary hypertension (SPH). The PAH patient (29-year-old male) had developed dyspnea, severe hypoxia and right ventricular heart failure without any family history. The SPH patient (16-year-old female) suffered from general fatigue, hypoxia and right ventricular heart failure due to a progressive atrial septal defect. As controls, normal pulmonary arterial smooth muscle cells (Nor-PASMCs) were isolated from the histologically normal pulmonary arteries of lung tissues resected from a patient (58-year-old male) with lung cancer. The PAH- and SPH-PASMCs were manually isolated from lung tissues that had developed severe plexiform lesions in the pulmonary arteries. The sections of the resected lung tissues were examined by hematoxylin-eosin staining and the PASMCs were then explanted, isolated and cultured in Dulbecco's modified Eagle's medium containing $10 \%$ fetal calf serum and $1 \%$ penicillin-streptomycin solution, as previously described. ${ }^{23,24}$ Until the scheduled experiments were carried out, the cells were cultured in $75 \mathrm{~cm}^{2}$ flasks at $37^{\circ} \mathrm{C}$ in a humidified atmosphere of $95 \%$ air $/ 5 \% \mathrm{CO}_{2}$. Cells were used for the scheduled experiments at passages 5-7. All human subject protocols were approved by the Ethics Committee of Okayama University Graduate School of Medicine, Dentistry and Pharmaceutical Sciences, and a written informed consent was obtained from all patients before the procedure. The investigation also conforms to the principles outlined in the Declaration of Helsinki.

\section{Total cellular RNA extraction and reverse transcriptase-PCR}

The PASMCs were grown in six-well plates to $\sim 80 \%$ confluence, and after the treatment indicated, the medium was removed and total cellular RNA was extracted by the isothiocyanate-acid-phenol-chloroform method using TRIzol (Invitrogen, Carlsbad, CA, USA) and quantified by measuring absorbance at $260 \mathrm{~nm}$. The RNA was stored at $-80^{\circ} \mathrm{C}$ until assays were performed. The expression of BMP/activin receptors, Smads, follistatin and noggin mRNAs were detected by reverse transcriptase (RT)-PCR. Oligonucleotides used for PCR were custom ordered from Invitrogen. PCR primer pairs for human BMP receptors, Smads and a house-keeping gene, ribosomal protein-L19, were selected from different exons of the corresponding genes to discriminate PCR products that might arise from possible chromosome DNA contaminants, as reported earlier. ${ }^{25}$ For AT1R, ET type-A (ETAR) and type-B receptors (ETBR), mineralocorticoid receptor (MR), noggin, activin receptor-like kinase (ALK)-1, Id-1 and 11 $\beta$-hydroxysteroid dehydrogenase type 2 (11ßHSD2), the following sequences were used: AT1R, 34-53 and 376-395 from GenBank accession number M93394; ETAR, 275-295 and 483-503 from L06622; ETBR, 931-951 and 1172-1192 from S44866; MR, 2730-2751 and 2971-2992 from M16801; noggin, 541-561 and 750-770 from NM_005450; ALK-1, 1160-1180 and 1501-1521 from NM_001077401; Id-1, 211-230 and 350-369 from X77956; and 11ßHSD2, 611-631 and 882-902 from U27317. The extracted RNA $(1 \mu \mathrm{g})$ was subjected to a RT reaction using First-Strand cDNA Synthesis System (Invitrogen) with random hexamers $\left(2 \mathrm{ng} \mathrm{\mu l}^{-1}\right)$, reverse transcriptase $(200 \mathrm{U})$ and deoxynucleotide triphosphate (dNTP; $0.5 \mathrm{~mm}$ ) at $42^{\circ} \mathrm{C}$ for $50 \mathrm{~min}$ and then at $70^{\circ} \mathrm{C}$ for $10 \mathrm{~min}$. Hot-start PCR was then performed using $\mathrm{MgCl}_{2}$ $(1.5 \mathrm{~mm}), \mathrm{dNTP}(0.2 \mathrm{~mm})$ and $2.5 \mathrm{U}$ of Taq DNA polymerase (Invitrogen) under the conditions as we have reported previously. ${ }^{25}$ Aliquots of the PCR products were electrophoresed on $1.5 \%$ agarose gels, visualized after ethidium bromide staining, photographed and scanned. 


\section{Quantitative real-time RT-PCR analysis}

For the quantification of Id-1, ETAR, ETBR, MR and 11ßHSD2 mRNA levels, real-time PCR was performed using the LightCycler-FastStart DNA master SYBR Green I system (Roche Diagnostic, Tokyo, Japan) under the optimized condition of annealing at $60^{\circ} \mathrm{C}$ with $4 \mathrm{mM} \mathrm{MgCl}_{2}$, following the manufacturers protocol. Accumulated levels of fluorescence for each product were analyzed by the second derivative method after the melting-curve analysis (Roche Diagnostic). Then, following assay validation by calculating the efficiency of each amplification reaction, the expression levels of target genes were quantified based on standard curve analysis for each product and normalized to the ribosomal protein-L19 level in each target.

\section{Genomic DNA extraction and sequence determination of BMPR2} gene

Genomic DNA was isolated from peripheral leukocytes of PAH patients using a genomic DNA isolation kit (Gentra Systems, Minneapolis, MN, USA) and each of the 12 exons of the BMPR2 gene were PCR amplified using corresponding primers that recognize each exon. ${ }^{5}$ The PCR products were then directly sequenced (ABI Prism 310, Applied Biosystems, Foster City, CA, USA).

\section{Thymidine incorporation assay}

The PASMCs $\left(1 \times 10^{4}\right.$ viable cells per well $)$ were precultured in 12 -well human fibronectin-coated plates (BD Biosciences, Bedford, MA, USA) containing $1 \mathrm{ml}$ culture medium. After the preculture period, the medium was replaced with fresh medium containing $1 \%$ fetal calf serum and the indicated concentrations of hormones and/or growth factors were added. After $24 \mathrm{~h}$ of treatment, $0.5 \mu \mathrm{Ci}$ per well of $\left[\right.$ methyl $\left.-{ }^{3} \mathrm{H}\right]$ thymidine (Amersham Pharmacia, Piscataway, NJ, USA) was added and incubated for $3 \mathrm{~h}$ at $37^{\circ} \mathrm{C}$. The incorporated thymidine was detected as previously reported. ${ }^{26}$ Cells were then washed with PBS, incubated with $10 \%$ ice-cold trichloroacetic acid for $30 \mathrm{~min}$ at $4{ }^{\circ} \mathrm{C}$ and solubilized in $0.5 \mathrm{M} \mathrm{NaOH}$, and their radioactivity was determined by a liquid scintillation counter (TRI-CARB 2300TR, Packard, Meriden, CT, USA).

\section{Western immunoblot analysis}

The PASMCs $\left(1 \times 10^{4}\right.$ viable cells per well $)$ were precultured in 12 -well plates in serum-free Dulbecco's modified Eagle's medium. After $24 \mathrm{~h}$ of preculture, the indicated concentrations of ET and aldosterone were added to the culture medium either alone or in combination with BMP-2 and BMP-7. After 15 or 60 min stimulation with hormones and/or growth factors, cells were solubilized in $100 \mu \mathrm{l}$ RIPA lysis buffer (Upstate Biotechnology, Lake Placid, NY, USA) containing $1 \mathrm{~mm} \mathrm{Na} \mathrm{VO}_{4}, 1 \mathrm{~mm} \mathrm{NaF}, 2 \%$ sodium dodecyl sulfate and $4 \% \beta$ mercaptoethanol. The cell lysates were then subjected to sodium dodecyl sulfate polyacrylamide gel electrophoresis/immunoblotting analysis using anti-phospho- and anti-total-extracellular signal-regulated kinase (ERK) 1/2 mitogenactivated protein kinase (MAPK) antibody, anti-phospho- and anti-total-P38 MAPK antibody, anti-phospho- and anti-total-stress-activated protein kinase/ c-Jun NH2-terminal kinase (SAPK/JNK) MAPK antibody, anti-phospho- and anti-total-Akt antibody and anti-phospho-Smad1/5/8 and anti-Smad5 antibody (Cell Signaling Technology, Beverly, MA, USA). The relative integrated density of each protein band was digitized by NIH image J 1.34s software.

\section{Statistical analysis}

All results are shown as mean \pm s.e.m. of data from at least three separate experiments, each performed in triplicate. Differences between groups were analyzed for statistical significance using analysis of variance (ANOVA) with Fisher's protected least significant difference test (StatView 5.0 software, Abacus Concepts, Berkeley, CA, USA). $P$-values $<0.05$ were accepted as statistically significant.

\section{RESULTS}

We first characterized the expression profile of key receptors, including Ang II, aldosterone and ET, and the BMP system molecules, including BMP type-I (ALK-2, ALK-3, ALK-4 and ALK-6) and type-II (ActRII, ActRIIB and BMPRII) receptors, binding proteins including follistatin and noggin, a TGF- $\beta$ type-I receptor (ALK-1), Smads1-8 in PASMCs isolated from normal controls (Nor-PASMCs), idiopathic pulmonary arterial hypertension (PAH-PASMCs) and secondary pulmonary arterial hypertension (SPH-PASMCs) (Figure 1). As shown in Figure 1a, AT1R, MR, ETAR and ETBR were expressed in PAH-, SPHand Nor-PASMCs as seen by RT-PCR. All of the type-I receptors examined were expressed in PAH-, SPH- and Nor-PASMCs. BMPRII and ActRII were expressed in PAH-, SPH- and Nor-PASMCs, although ActRIIB was not detected in Nor-PASMCs. Follistatin and noggin were also detected in the three types of PASMCs, with noggin expression in PAH-PASMCs being comparably lower than that of SPH- and NorPASMCs. PAH- and SPH-PASMCs expressed receptor-specific Smads1, 2, 3, 5 and 8, a common Smad4 and inhibitory Smads6 and 7, whereas Nor-PASMCs lacked Smad8 expression. Direct sequencing of PCR products from all 12 exons of the BMPR2 gene ${ }^{5}$ found no $B M P R 2$ mutations in the genomic DNA of the patient from whom we collected the PAH-PASMCs. BMPRII mRNA, including the N-terminus region, which encodes the extracellular and transmembrane domains, was expressed in all three types of PASMCs. To compare the BMPR signal activities in PAH- and SPH-PAMSCs, the transcription of a BMP target gene (Id-1) was examined in PASMCs treated with BMP-2, BMP-4, BMP-6 and BMP-7 for 24h. As shown in Figure 1b, BMP-2, BMP-4, BMP-6 and BMP-7 all increased Id-1 mRNA levels in PAH- and SPH-PASMCs by the same amount.

We next examined the effects of ET on mitosis of PASMCs isolated from idiopathic and secondary PAH patients. The mitotic activity of PASMCs was quantified by a thymidine incorporation assay. As shown in Figure 1c, ET1 induced cell proliferation of PAH- and SPHPASMCs in a concentration-dependent manner for $24 \mathrm{~h}$, in which the maximal effects of ET1 on PAH-PASMCs were higher compared with the effects on SPH-PASMCs. In contrast to ET1, ET3 treatment failed to induce significant mitotic activity in both $\mathrm{PAH}-$ and $\mathrm{SPH}-$ PASMCs. Bosentan, a competitive ET1 antagonist that inhibits binding to both ETAR and ETBR, reduced basal mitotic activity in both PASMC types. Bosentan $(3-30 \mu \mathrm{M})$ treatment reversed ET1-induced cell proliferation, and $30 \mu \mathrm{m}$ bosentan abolished the effect of ET1 on mitosis of both PASMC types.

Next, to investigate the contribution of RAAS to PASMC mitosis, cells were treated with Ang II for $24 \mathrm{~h}$ (Figure 2). As shown in Figure $2 \mathrm{a}$ and $\mathrm{b}$, Ang II (30-300 nM) had no significant effects on the mitosis of either PASMC type. In addition, candesartan, an AT1R antagonist, at a concentration of $1-10 \mathrm{nM}$, failed to reverse ET1-induced cell proliferation in these PASMCs. Notably, aldosterone (1-300 nм) elicited potent mitotic activity in PAH-PASMCs in a concentrationdependent manner (Figure 2c). The effects of aldosterone on PASMC mitosis were prominent in PAH-PASMCs compared with SPHPASMCs (Figure 2d). An MR antagonist, eplerenone (100-300 nM), abolished aldosterone-induced mitotic activity, although eplerenone alone had no significant suppression of basal cell proliferation in both types of PASMCs (Figures $2 \mathrm{c}$ and $\mathrm{d}$ ).

Because the BMP system, including type-I and -II receptors and Smads, was found to be present in both PASMC types, we next examined whether this receptor system is functional. To evaluate the effect of each BMP ligand, cells were cultured in the presence of four BMP ligands (Figure 3). As we have previously shown, the effects of each individual BMP ligands on PASMC mitosis differed, with BMP-2 and BMP-7 acting as stimulators of mitosis of PAH-PASMCs. ${ }^{26}$ As shown in Figures 3a and c, BMP-2 and BMP-7 (10-100 $\mathrm{ng} \mathrm{m}^{-1}$ ) induced mitosis in both PAH- and SPH-PASMCs. In contrast, BMP-4 and BMP-6 had no effect on PASMC mitogenicity. PDGF-BB $\left(100 \mathrm{ng} \mathrm{ml}^{-1}\right)$, which is known to be a potent PASMC growth factor, ${ }^{8}$ increased DNA synthesis by both PASMC types by up to 
a

PAH-PASMC

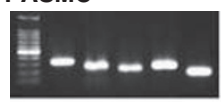

SPH-PASMC
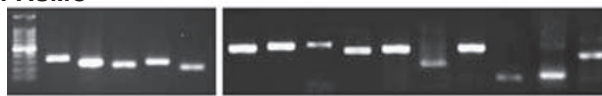

Nor-PASMC
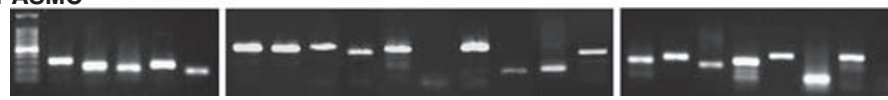

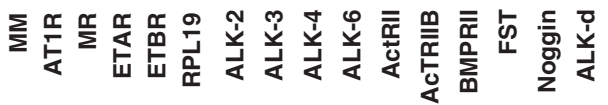

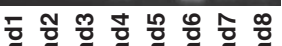

b

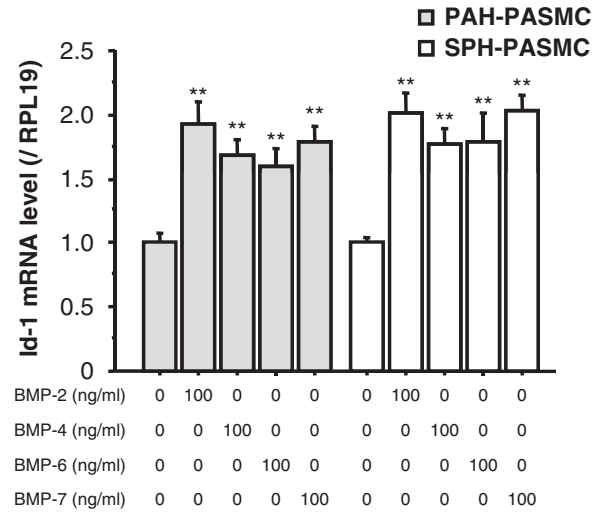

C

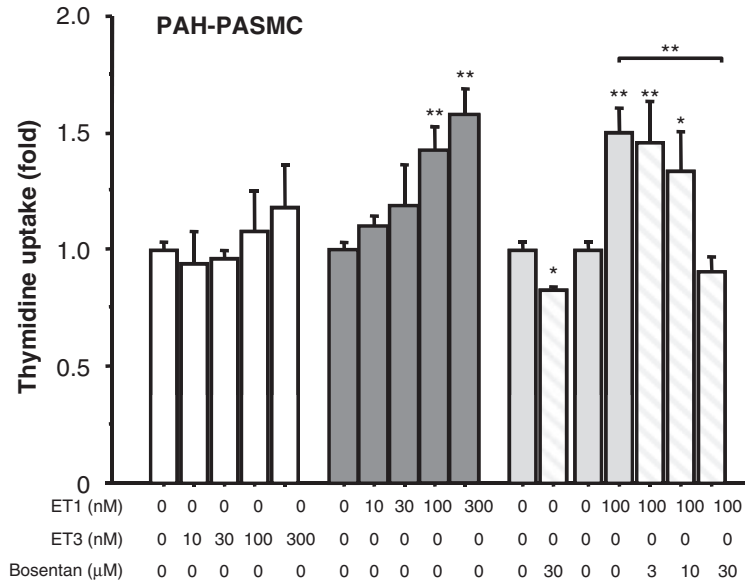

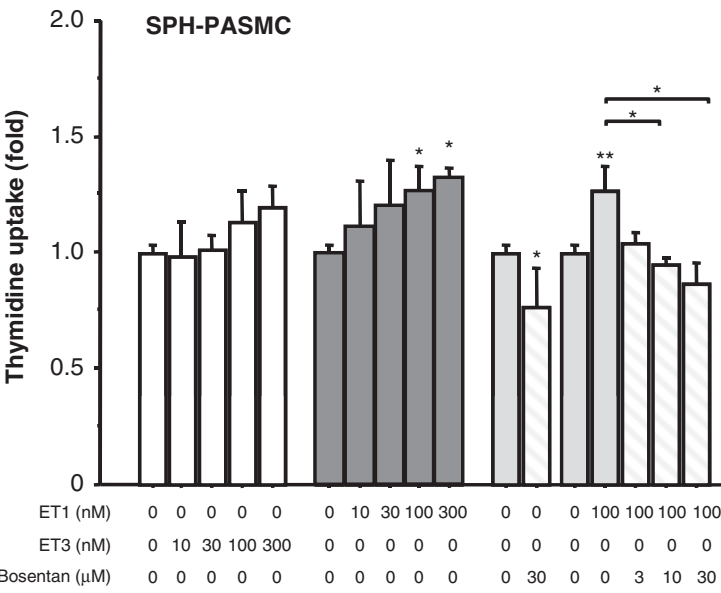

Figure 1 Characterization of BMP, endothelin and the angiotensin-aldosterone system in isolated PASMCs. (a) Total cellular RNA was collected from cultured PAH-, SPH- and Nor-PASMCs. Expression of mRNAs encoding angiotensin II type-1 receptor (AT1R), mineralocorticoid receptor (MR), endothelin type-A and type-B receptor (ETAR and ETBR), BMP/activin/TGF- $\beta$ type-2 ${ }^{2}$ (ALK-1, ALK-2, ALK-3, ALK-4 and ALK-6) and BMP/activin type-22 receptors (ActR ${ }^{22}$, ActR ${ }^{22}$ B and BMPR ${ }^{22}$ ), BMP/activin-binding proteins (follistatin; FST and noggin) and the Smad signaling molecules (Smad1-8) were examined by RT-PCR in PAH-, SPH- and Nor-PASMCs. MM indicates the molecular weight marker. (b) PASMCs were treated with BMP-2, BMP-4, BMP-6 and BMP-7 (100 ng ml ${ }^{-1}$ ) for $24 \mathrm{~h}$. Total cellular RNA was extracted and the Id-1 mRNA level was examined by quantitative real-time PCR. The expression level of Id-1 was standardized by ribosomal protein L19 (RPL19) level in each sample. (c) PAH- and SPH-PASMCs were cultured in DMEM containing $1 \%$ FCS and treated with the indicated concentrations of endothelin-1 (ET1; 10-300 nм) and endothelin-3 (ET3; 10-300 nм) in combination with bosentan (3-30 $\mu \mathrm{m})$ for $24 \mathrm{~h}$ followed by a $3 \mathrm{~h}$ pulse exposure of $0.5 \mu \mathrm{Ci}$ per well of thymidine. The thymidine level incorporated into the cells was counted. Results are shown as the mean $\pm \mathrm{s}$.e.m. of data from three separate experiments, each performed in triplicate; ${ }^{*} P<0.05$ and ${ }^{*} P<0.01$ vs. control groups and between the indicated groups.

approximately twofold (Figure 3). We further examined the functional interrelationship between the BMP system and ET1 or aldosterone in PASMC proliferation. As shown in Figures $3 \mathrm{~b}$ and d, cells were treated with BMP-2 and BMP-7 (10-100 $\left.\mathrm{ng} \mathrm{ml}^{-1}\right)$ in combination with either ET1 (10-100 nM) or aldosterone (10-100 nM). In PAH-PASMCs, ET1 and aldosterone additively enhanced BMP-2- and BMP-7-induced cell mitosis (Figure 3b). However, in SPH-PASMCs, neither ET1 nor aldosterone had any significant effect on BMP-2- and BMP-7-induced cell mitosis (Figure 3d).

To investigate the mechanism by which ET1 and aldosterone augment BMP actions in PAH-PASMCs, we examined key signaling pathways, including MAPK and AKT, in PASMCs. Cell mitosis in most smooth muscle cell types is generally associated with activation of the MAPK pathway. Recent studies have shown crosstalk between BMP-Smad signaling and the MAPK pathway in various cell types. ${ }^{27}$ As shown in Figure 4a, PASMCs were stimulated with aldosterone, Ang II, ET1, ET3 and PDGF-BB in serum-free conditions for $15 \mathrm{~min}$. ET1 (100 nM) stimulated ERK1/ERK2 and SAPK/JNK phosphorylation in PAH-PASMCs, whereas the ET1 effects on ERK1/ERK2 signal were less potent in SPH-PASMCs (Figure 4a). ET3 also activated ERK1/ERK2 and SAPK/JNK phosphorylation in both PASMC types; however, the effects of ET3 were much less potent than that of ET1. On the contrary, ET1 did not affect P38-MAPK and AKT signaling in either PASMC type. In addition, the effects of aldosterone and Ang II $(100 \mathrm{~nm})$ alone were negligible with regard to MAPK and AKT activation in both PAH- and SPH-PASMCs (Figure 4a).

To investigate the involvement of MAPK signaling in PASMCs, we used specific inhibitors of ERK1/ERK2 and SAPK/JNK pathways, U0126 and SP600125, respectively. As shown in Figure 4b, treatment with U0126 (0.3-3 $\mu \mathrm{M})$ suppressed basal mitotic activity of both PASMC types, whereas the effects of SP600125 (0.3-3 $\mu \mathrm{M})$ were less potent. The effects of these MAPK inhibitors on PASMC mitosis were further evaluated in the presence of ET1 and aldosterone. The mitotic action induced by either ET1 or aldosterone was restored by MAPK inhibition, with the effects of U0126 significantly more effective than those of SP600125 (Figure 4b). Thus, the mitotic effects induced by ET1 and aldosterone seemed to occur, at least in part, through activation of the MAPK pathway in both PAH- and SPH-PASMCs. 
a

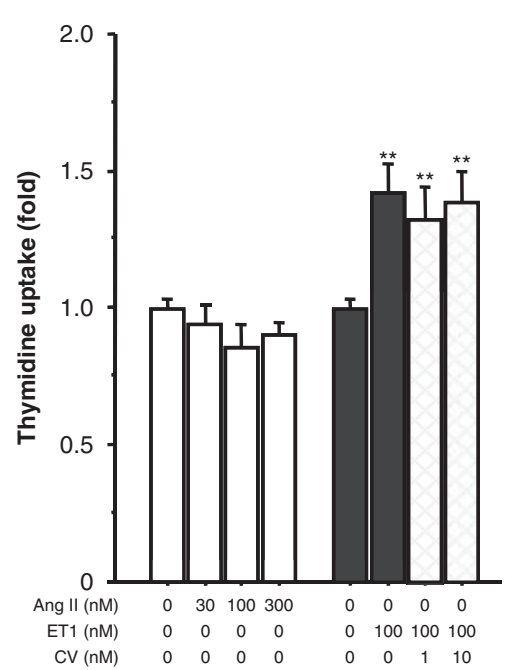

b

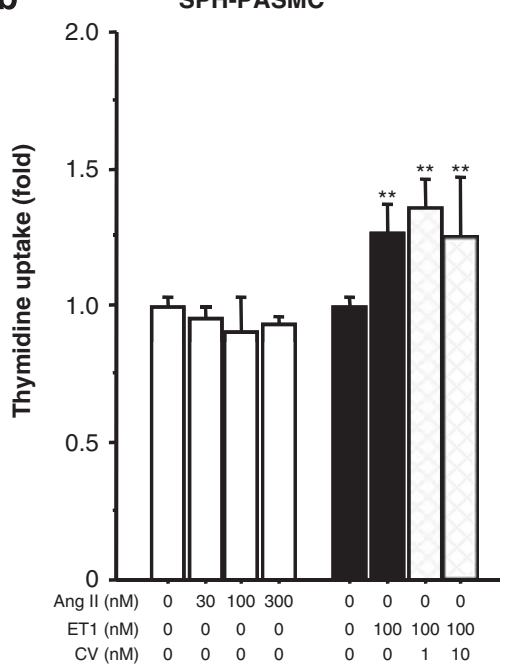

C

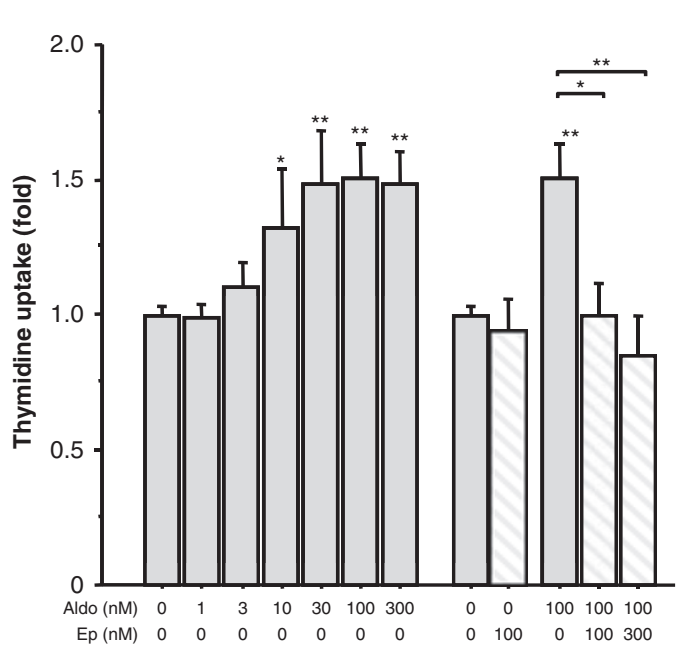

d

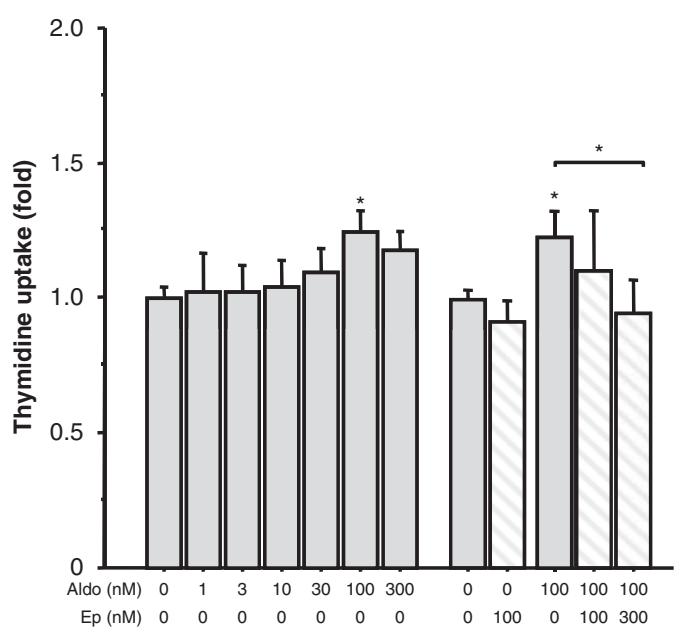

Figure 2 Effects of angiotensin II (Ang II) and aldosterone on PASMC mitosis. PAH- and SPH-PASMCs were cultured in DMEM containing $1 \%$ FCS and treated with Ang II (30-300 nm) and ET1 (100 nm) in combination with Ang II type-1 receptor (AT1R) antagonist, candesartan (CV; 1-10 nM) (a, b); or treated with aldosterone (Aldo; 1-300 nm) in combination with MR antagonist, eplerenone (Ep; 100-300 nM) (c, d) for $24 \mathrm{~h}$ followed by a $3 \mathrm{~h}$ pulse exposure of $0.5 \mu \mathrm{Ci}$ per well of thymidine. The thymidine level incorporated into cells was counted. Results show the mean \pm s.e.m. of data from three separate experiments, each performed in triplicate; ${ }^{*} P<0.05$ and ${ }^{*} P<0.01$ vs. control groups and between the indicated groups.

To further estimate the signal crosstalk between BMP and MAPK in PASMCs, cells were cotreated with BMP-2 or BMP-7 in combination with ET1 and aldosterone. As shown in Figure 5, BMP-2 and BMP-7, which stimulated cell mitosis in both PASMC types through Smad1/5/ 8 phosphorylation, had no effect on MAPK activation (including ERK1/ERK2 and SAPK/JNK). Notably, ET1-induced phosphorylation of ERK1/ERK2 and SAPK/JNK was enhanced in the presence of BMP2 and BMP-7 in PAH-PASMCs (Figure 5a). BMP-2 and BMP-7 also upregulated ERK1/ERK2 and SAPK/JNK phosphorylation in the presence of aldosterone in PAH-PASMCs, although aldosterone alone did not activate the ERK1/ERK2 and SAPK/JNK pathways (Figure 5b). In the case of SPH-PASMCs, the combined effects of ET1 and either BMP-2 or BMP-7 on MAPK activation were only marginally detected (Figure 5a). No additive effects of aldosterone and either BMP-2 or BMP-7 on MAPK were observed in SPH-PASMCs (Figure 5b).
To characterize the differences of ET1 and aldosterone sensitivities on PASMC mitosis between PAH- and SPH-PASMCs, the expression levels of ETAR, ETBR, MR and 11ßHSD2 were examined by real-time PCR (Figure 6). As shown in Figure 6a, basal levels of ETAR and ETBR mRNA were relatively high, but the level of $11 \beta \mathrm{HSD} 2$ mRNA was lower in PAH-PASMCs compared with SPH-PASMCs. We next examined the effects of endogenous BMPs on ET receptors and MR expression in PASMCs using the BMP-binding protein, noggin, which neutralizes broad BMP actions. Noggin treatment $\left(30 \mathrm{ng} \mathrm{ml}^{-1}\right)$ suppressed the expression levels of ETAR and ETBR in PAH-PASMCs for $24 \mathrm{~h}$, whereas it increased ETAR and ETBR expression in SPHPASMCs (Figure 6b), suggesting that endogenous BMPs act to upregulate ET receptors in PAH-PASMCs and downregulate those of SPH-PASMCs. MR expression was not affected by noggin in either PASMC type. Furthermore, BMP-2 and BMP-7 upregulated ETAR and ETBR mRNA expression, whereas ET1 had no effect on ET 

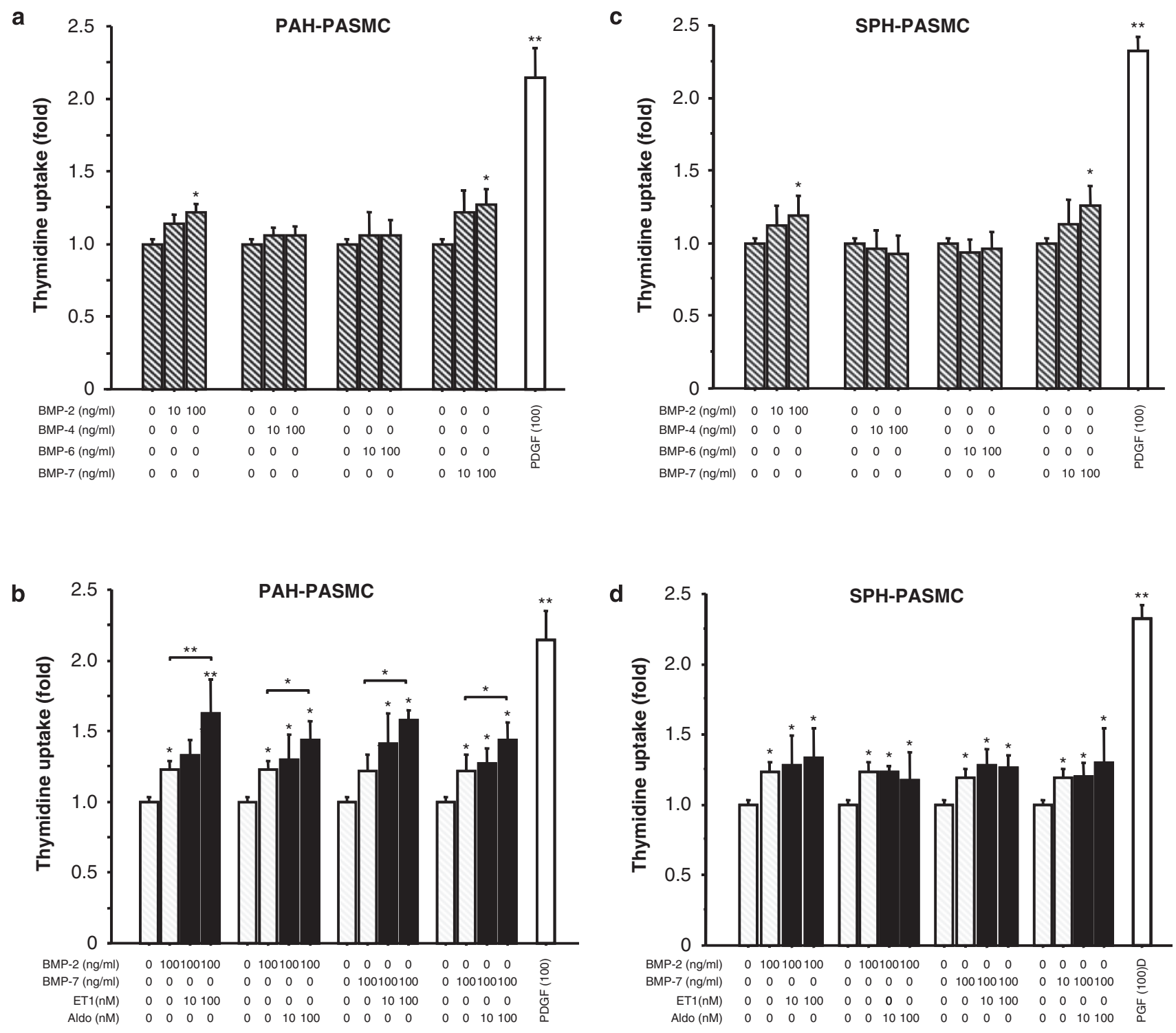

Figure 3 Combined effects of BMP, endothelin and aldosterone on PASMC mitosis. PAH- and SPH-PASMCs were cultured in DMEM containing $1 \%$ FCS and treated with BMP-2, BMP-4, BMP-6 and BMP-7 (10-100 $\mathrm{ng} \mathrm{ml}^{-1}$ ) and PDGF-BB (100 ng ml-1) (a, c); or treated with endothelin-1 (ET1; 10 and 100 nM) and aldosterone (Aldo; 10 and $100 \mathrm{~nm}$ ) in combination with BMP-2 and BMP-7 (100 ng ml-1) (b, d) for $24 \mathrm{~h}$ followed by a $3 \mathrm{~h}$ pulse exposure of $0.5 \mu \mathrm{Ci}$ per well of thymidine. The thymidine level incorporated into cells was counted. Results show the mean \pm s.e.m. of data from three separate experiments performed in triplicate; ${ }^{*} P<0.05$ and ${ }^{*} P<0.01$ vs. control groups and between the indicated groups.

receptor expression in PAH-PASMCs (Figure 6c). MR expression was also upregulated by BMP-2 and BMP-7, whereas 11ßHSD2 mRNA level was decreased by BMP-2 in PAH-PASMCs (Figure 6c). In contrast to PAH-PASMCs, ETBR and MR expression was decreased by treatment with BMP-2, BMP-7 and ET1, and the expression of $11 \beta \mathrm{HSD} 2$ was reduced by BMP-2 and BMP-7 in SPH-PASMCs (Figure 6c).

\section{DISCUSSION}

In this study, we have shown a novel interaction between BMP signaling and other mitogenic actions (Figure 7), namely, (1) PAHPASMCs had higher mitotic activity through MAPK in response to ET1 compared with SPH-PASMCs, in which the mitotic activity induced by ET1 was significantly inhibited by bosentan; (2) PAHbut not SPH-PASMCs had mitotic sensitivity in response to not only ET1 but also aldosterone; (3) ET1 and aldosterone elicited additive effects on PAH-PASMC mitosis and MAPK stimulation, preferentially in the presence of BMP-2 and BMP-7, in which ERK was functionally linked to the mitogenesis of PASMCs; and (4) ET receptor expression was relatively high in PAH-PASMCs, and ET receptors and MR were upregulated by BMP-2 and BMP-7.

It is well known that increased production of mitogenic agonists, such as ET1 and PDGF, in circulation and lung tissues is linked to the development of pulmonary vascular remodeling. ${ }^{10,11,28}$ Enhanced local production of ET1 by pulmonary vascular endothelial cells correlates with the severity of pulmonary vascular remodeling, suggesting a causal role for ET1 in the development of PAH. ${ }^{28,29} \mathrm{ET} 1$ is a potent pulmonary vasoconstrictor as well as a PASMC mitogen, ${ }^{17,18,30}$ and ET1 also has antiapoptotic effects on vascular cells, including endothelial cells, fibroblasts and systemic smooth muscle cells. ${ }^{31,32}$ The mechanism of ET1 action on PASMC involves binding to ET receptors with subsequent phospholipase $\mathrm{C}$ activation, which causes hydrolysis 
a

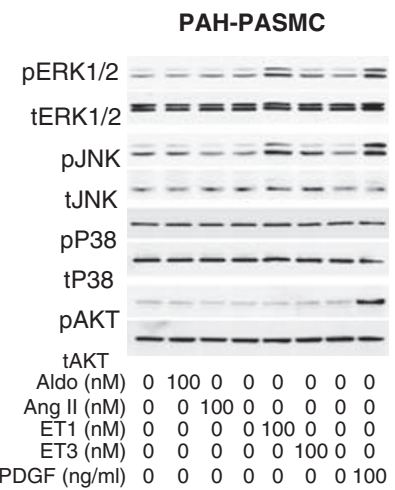

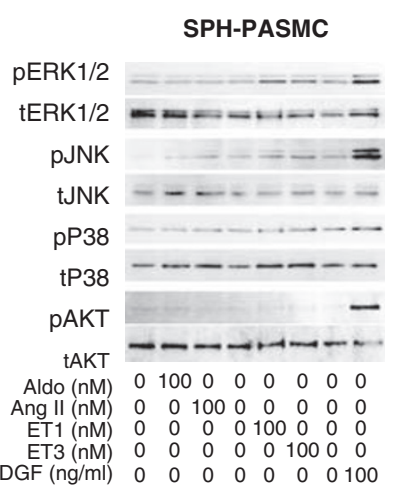

b

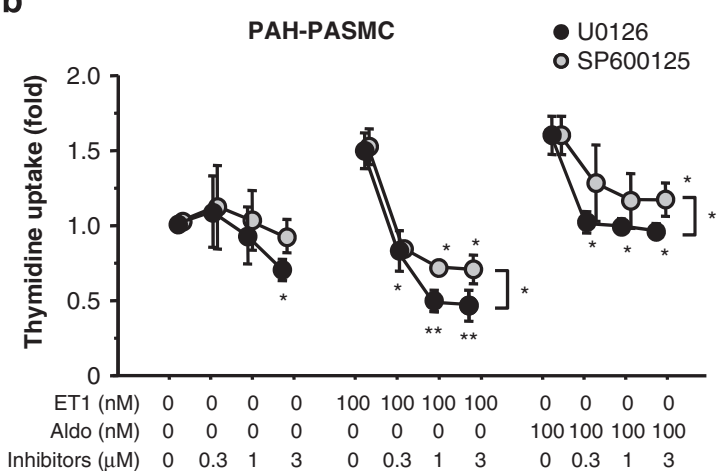

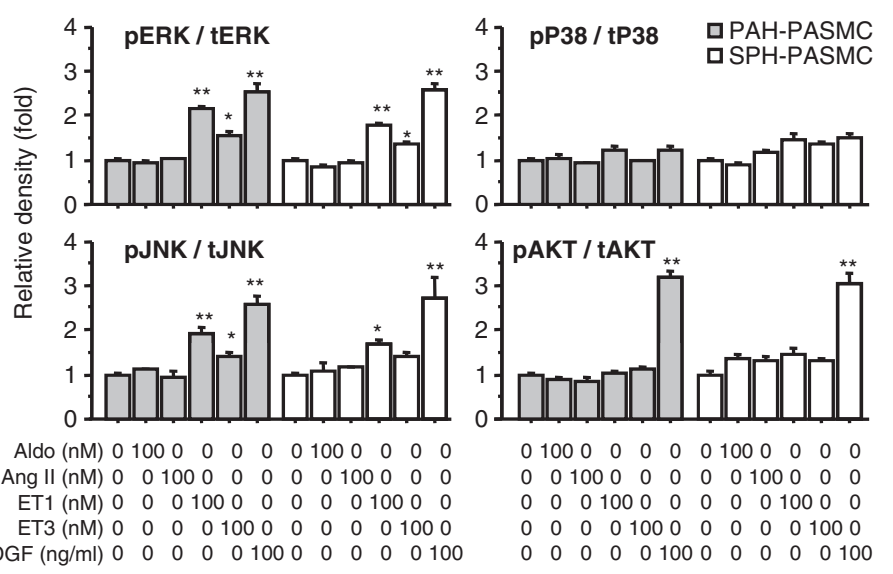

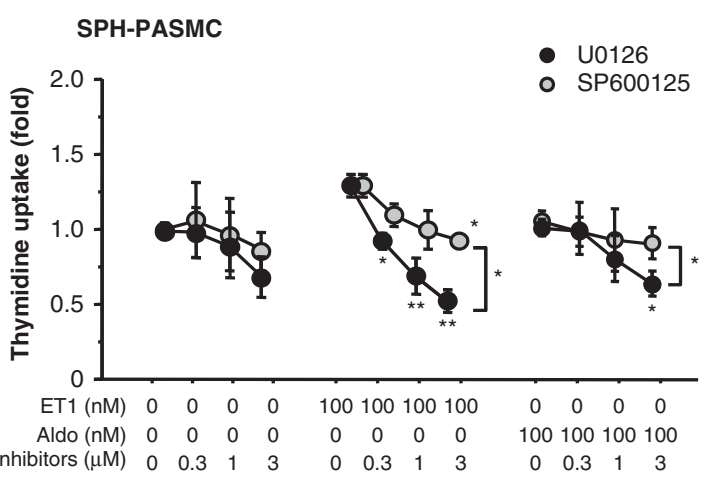

Figure 4 Effects of aldosterone, angiotensin II and endothelin on MAPK pathway in PASMCs. (a) PASMCs were precultured in serum-free DMEM for $24 \mathrm{~h}$ and stimulated with the indicated concentrations of aldosterone (Aldo), angiotensin II (Ang II), endothelin-1 and endothelin-3 (ET1 and ET3) and PDGF-BB. After a 15 min culture, cells were lysed and subjected to SDS-PAGE/immunoblot analysis using anti-phospho-ERK1/2 (pERK1/2), anti-total-ERK1/2 (tERK1/ 2), anti-phospho-SAPK/JNK (pJNK), anti-total-SAPK/JNK (tJNK), anti-phospho-P38 (pP38), anti-total-P38 (tP38), anti-phospho-AKT (pAKT) and anti-totalAKT (tAKT) antibodies. The results shown are representative of those obtained from three independent experiments. The relative integrated density of each protein band was digitized by NIH image J 1.34s software (lower panel). (b) PAH- and SPH-PASMCs were cultured in DMEM containing $1 \%$ FCS and treated with indicated concentrations of $\mathrm{U} 0126(0.3-3 \mu \mathrm{M})$ and SP600125 (0.3-3 $\mu \mathrm{m})$ in the absence or presence of endothelin-1 (ET1; $100 \mathrm{nm)}$ or aldosterone (Aldo; $100 \mathrm{~nm}$ ) for $24 \mathrm{~h}$ followed by a $3 \mathrm{~h}$ pulse exposure of $0.5 \mu \mathrm{Ci}$ per well of thymidine. The amount of thymidine incorporated into cells was counted. Results show the mean \pm s.e.m. of data from three separate experiments each performed in triplicate; ${ }^{*} P<0.05$ and ${ }^{* *} P<0.01$ vs. control groups and between the indicated groups.

of phosphatidylinositol and generation of cytosolic inositol trisphosphate, leading to an increase of $\mathrm{Ca}^{2+}$ influx and the induction of cell contraction and membrane-bound diacylglycerol production. Diacylglycerol then activates PKC and triggers intracellular mechanisms that promote cell proliferation and migration through MAPK. ${ }^{33}$ Thus, ET receptor signaling is indirectly, but functionally, linked to the MAPK cascade.

Bone morphogenetic protein ligands transduce their signals through two types of serine/threonine kinase receptors, type-I and II receptors, both of which are required for signal transduction. ${ }^{34,35}$ On binding of BMPs, type-II receptors phosphorylate the corresponding type-I receptors, which in turn phosphorylate the intracellular signal-transducing molecules Smad1/5/8. Among the BMP ligands examined, we show that BMP-2 and BMP-7 are stimulatory factors for PAH-PASMC mitosis. The ALK-6/BMPRII receptor pair is recognized to be the common functional complex for BMP-2 and BMP-7. 35,36 Earlier, we showed the roles of BMP ligands and type-I receptors in PASMC physiology, both of which must interact with BMPRII for the propagation of BMPRII signaling, as BMP effects including its signaling and mitogenicity were abolished by the inhibition of ALK-6 with dominant-negative and siRNA techniques. ${ }^{26}$ Thus, the underlying mechanism by which BMP regulates cell mitosis also includes the interaction between BMP ligands and type-I receptors in PAHPASMCs.

Identification of increased ET1 levels has led to the development of ET receptor antagonists, which have improved the course of the disease for many PAH patients. ${ }^{37,38}$ Star et al. showed an interesting finding that BMP-2 and BMP-7, but not BMP-4, increased ET1 production by human pulmonary microvascular endothelial cells, with increased phosphorylation of Smad1/5 levels. ${ }^{39}$ In our present data, basal expression of ETAR and ETBR in PASMCs was relatively high in PAH lungs compared with SPH, in which expression of both ET receptor types was decreased by treatment with the BMP-binding protein noggin, whereas it was increased by BMP-2 and BMP-7 in PAH-PASMCs. Thus, the BMP and ET systems synergistically facilitate PASMC proliferation in PAH lungs through the enhancement of ET1induced MAPK activation with upregulation of ET receptors.

As for the roles of RAAS in the pathogenesis of PAH, we showed that aldosterone is also functionally involved in PASMC mitosis. Generally, in epithelial cells, MR is protected from excessive cortisol by coexpression of $11 \beta \mathrm{HSD} 2$, which converts active cortisol to inactive cortisone in vivo. ${ }^{40,41}$ In contrast, in nonepithelial tissues that do not express $11 \beta \mathrm{HSD} 2, \mathrm{MR}$ is generally understood to be overwhelmingly occupied by existing cortisol rather than aldosterone in vivo. 


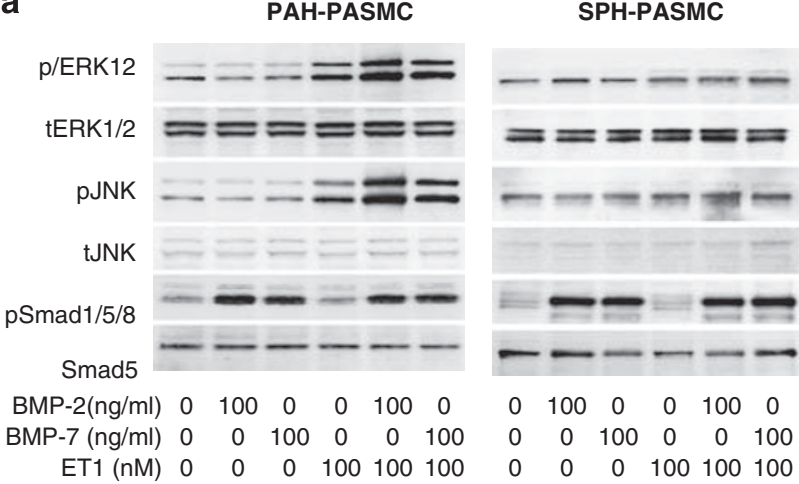

b

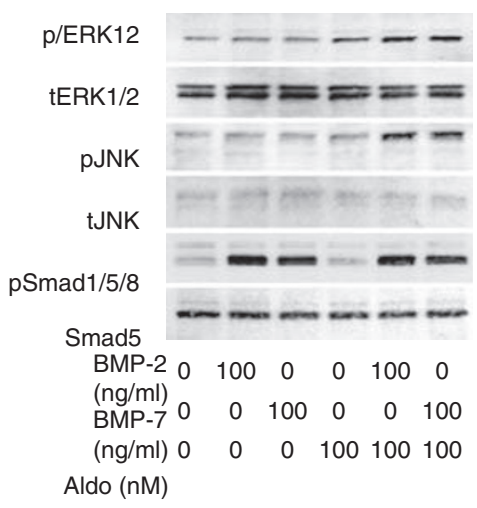

SPH-PASMC

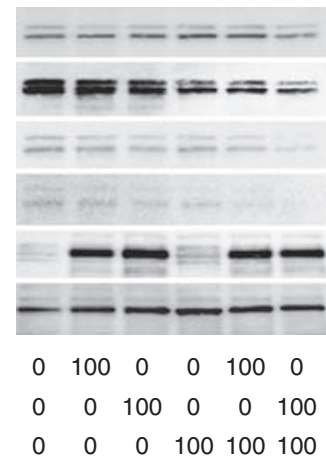

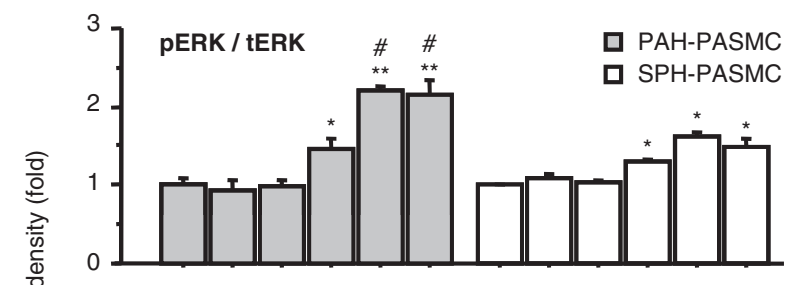
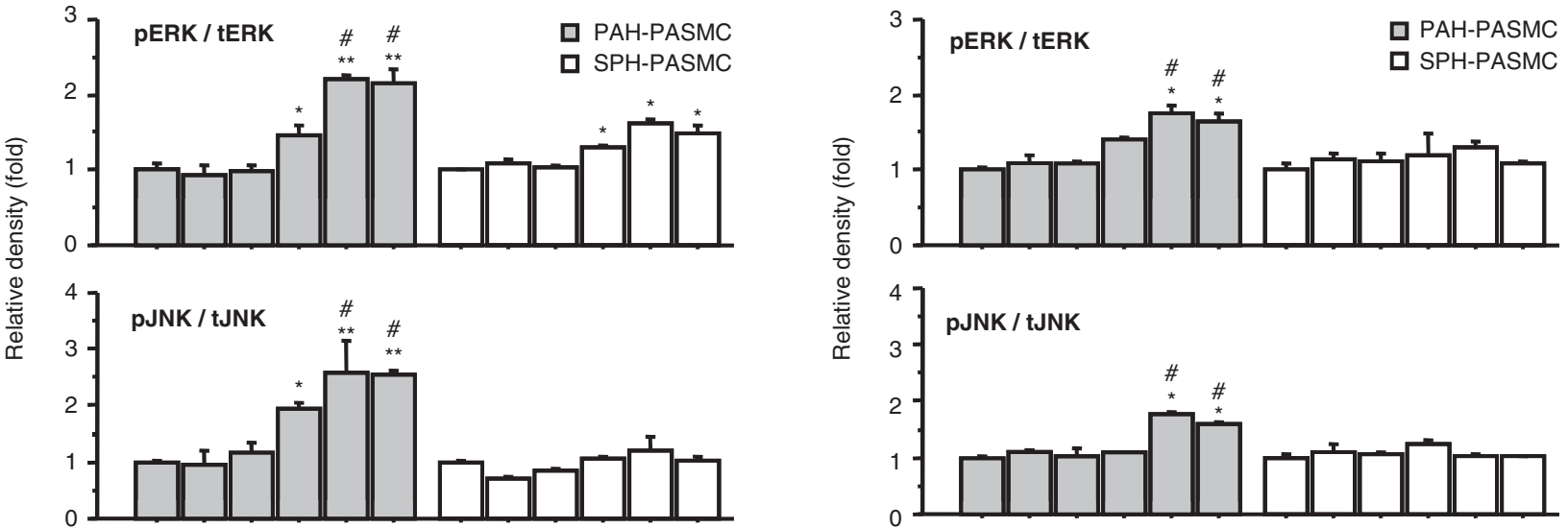

BMP-2 (ng/ml) $0 \begin{array}{llllllllllll}100 & 0 & 0 & 100 & 0 & 0 & 100 & 0 & 0 & 100 & 0\end{array}$

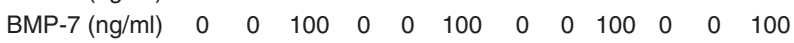

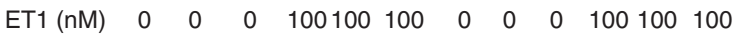

Figure 5 Effects of BMP on endothelin- and aldosterone-induced MAPK activation in PASMCs. PASMCs were precultured in serum-free DMEM for $24 \mathrm{~h}$ and stimulated with BMP-2 $\left(100 \mathrm{ng} \mathrm{ml}^{-1}\right)$ and BMP-7 $\left(100 \mathrm{ng} \mathrm{ml}^{-1}\right)$ in the absence or presence of (a) endothelin-1 (ET1; $100 \mathrm{nm)} \mathrm{and} \mathrm{(b)} \mathrm{aldosterone} \mathrm{(Aldo;}$ $100 \mathrm{~nm}$ ). After a $60 \mathrm{~min}$ culture, cells were lysed and subjected to SDS-PAGE/immunoblot analysis using anti-pERK1/2, tERK1/2, pJNK, tJNK, pSmad1/5/8 and Smad5 antibodies. The results shown are representative of those obtained from three independent experiments. The relative integrated density of each protein band was digitized by $\mathrm{NIH}$ image $\mathrm{J} 1.34 \mathrm{~s}$ software (lower panel). Results are shown as mean \pm s.e.m. of data from at least three separate experiments, each performed in triplicate; ${ }^{*} P<0.05$ and ${ }^{* *} P<0.01$ vs. control groups; ${ }^{\#} P<0.05$ vs. ET1- or Aldo-treated groups.

In aldosterone target cells, $11 \beta \mathrm{HSD} 2$ has crucial roles in conferring aldosterone sensitivity on MR by inactivating intracellular glucocorticoids before they occupy MR. In the present study, basal expression of $11 \beta H S D 2$ in PASMCs was relatively low in PAH lungs compared with SPH. The inhibitory effects of BMP-2 on 11ßHSD2 expression and the MR upregulation by BMP-2 and BMP-7 may further enhance MR actions on PAH-PASMC mitosis in response to endogenous mineralocorticoids and glucocorticoids in vivo. In addition to the genomic actions of aldosterone mediated through regulation of nuclear gene transcription and protein synthesis, aldosterone also elicits rapid and potentially nongenomic responses, including intracellular calcium, PKC, MAPK, Rho-kinase and PI3K, in a variety of cells. ${ }^{42}$ The interaction between MR and its nongenomic responses is still controversial. Nevertheless, our data showed that eplerenone possibly inactivates aldosterone-induced PASMC mitosis in PAH lungs, suggesting the possibility of clinical application of MR antagonists for controlling PAH pathogenesis.

Unbalanced Smad signaling induced by BMP and TGF- $\beta$ is functionally involved in the pathogenesis of PAH. Among the BMPRII mutants reported in PAH patients, Nishihara et al. ${ }^{43}$ showed that missense mutations within the extracellular and kinase domains of
BMPRII abrogate signal transduction, which seems to be caused in part by the altered localization of these receptor domains. In contrast, BMPRII mutants with truncated cytoplasmic tails retained the ability to transduce normal BMP signaling, suggesting that BMPRII cannot be a single factor for PAH pathogenesis. ${ }^{43}$ These findings have raised the possibility of the involvement of additional genetic and/or somatic factors to trigger the development of PAH lesions and further imply that causal factors for PAH development are heterogenous.

Our present study revealed that mitotic effects of ET1, aldosterone and PDGF are, at least in part, MAPK (ERK1/2 and SAPK/JNK)dependent. There is increasing evidence that other signaling pathways may also be involved in mediating BMP actions. Examples include TGF- $\beta$-activated kinase-1, a member of the MAPK kinase kinase family, ${ }^{44}$ which is activated by BMP- 4 or TGF- $\beta,{ }^{44,45}$ and the Ras/ Rac families of small GTP-binding proteins, which are also implicated in TGF- $\beta$ signaling. Moreover, the ERK1/ERK2 and SAPK/JNK pathways are linked to TGF- $\beta$ /BMP signal transduction in some cell types. ${ }^{46-48}$ The data provided here show that the MAPK pathway is functionally involved in PAH-PASMC mitosis, which is facilitated under the presence of combined stimuli of either ET1 or aldosterone and the BMP system. 

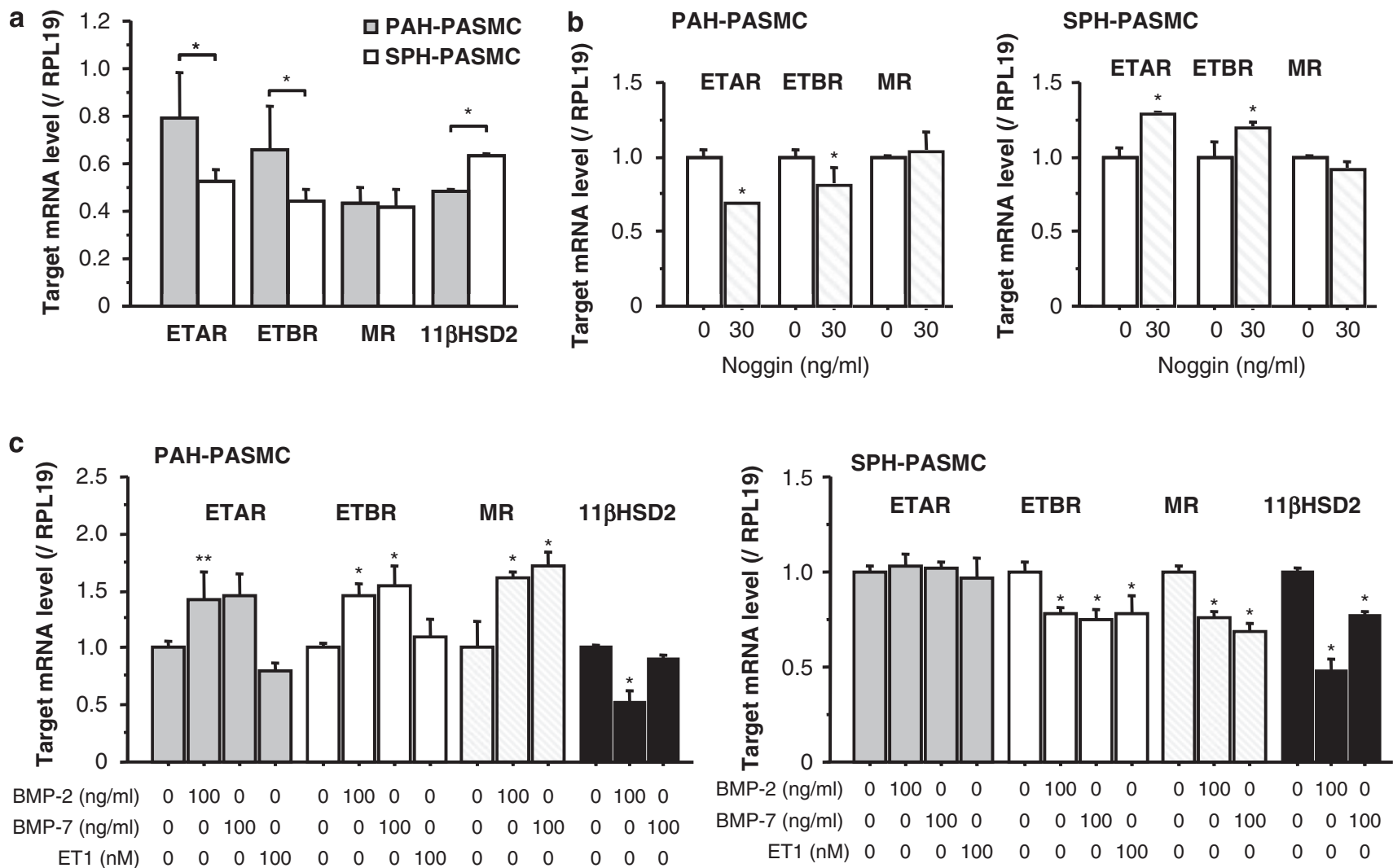

Figure 6 Effects of BMP on the expression of endothelin and mineralocorticoid receptors in PASMCs. (a) Total cellular RNA was extracted from PAH- and SPH-PASMCs, and the basal expression levels of ETAR, ETBR, MR and 11ßHSD2 mRNA levels were examined by quantitative real-time PCR. (b, $\mathbf{c}$ ) PASMCs were treated with noggin $\left(30 \mathrm{ng} \mathrm{ml}^{-1}\right)$, BMP-2 and BMP-7 $\left(100 \mathrm{ng} \mathrm{ml}^{-1}\right)$ in combination with endothelin-1 (ET1; $100 \mathrm{nm)} \mathrm{for} 24 \mathrm{~h}$. The expression levels of target genes were normalized to the RPL19 level in each sample. Results show the mean \pm s.e.m. of data from three separate experiments, each performed in triplicate; ${ }^{*} P<0.05$ vs. control groups and between the indicted groups.

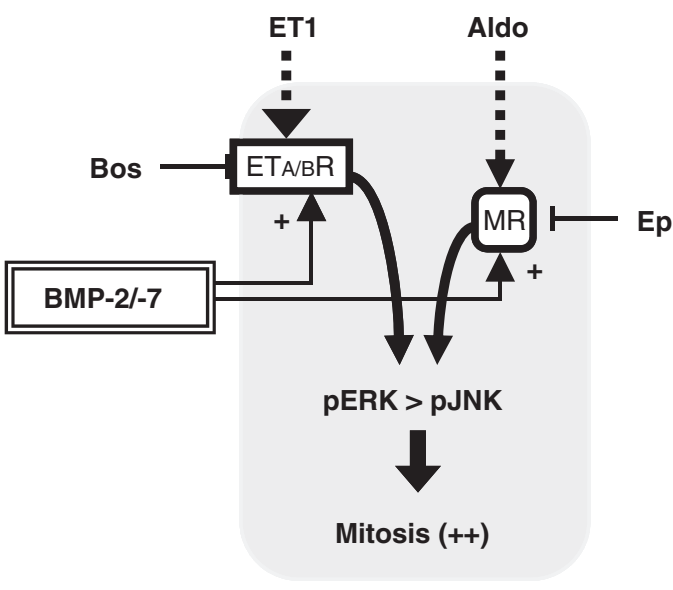

PAH-PASMC

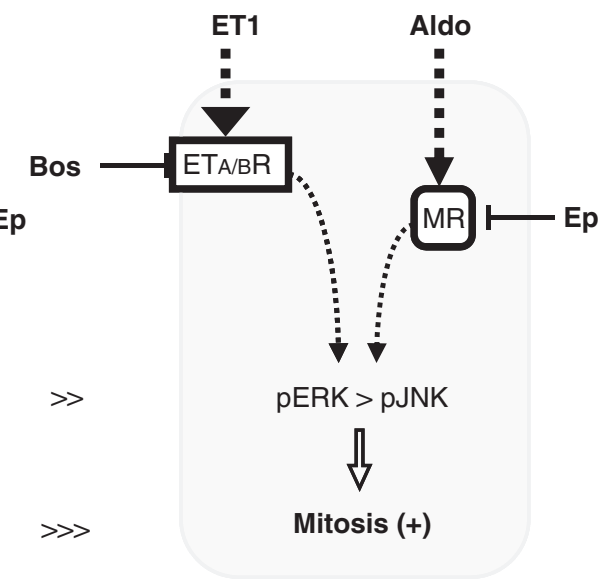

SPH-PASMC

Figure 7 Possible interaction between endothelin, aldosterone and BMP receptor signaling in PASMC proliferation. PAH-PASMCs had higher mitotic activity and capacity of MAPK phosphorylation in response to endothelin-1 (ET1) compared with SPH-PASMCs. The mitotic activity induced by ET1 and aldosterone (Aldo) is inhibited by bosentan (Bos) and eplerenone (Ep), respectively. PAH-PASMCs, but not SPH-PASMCs, also had mitotic sensitivity in response to Aldo. ET1 and Aldo elicit additive effects on PAH-PASMC mitosis and MAPK activation, preferentially in the presence of BMP-2 and BMP-7. The expression of ET type-A/B receptors $\left(E_{A / B} R\right)$ and mineralocorticoid receptor $(M R)$ in PAH-PASMCs was also upregulated in the presence of BMP-2 and BMP-7.

Collectively, the present data suggest that the BMP system may upregulate mitogenic sensitivity to exogenous ET1 and aldosterone in PAH-PASMCs. This could be a feature distinct from SPH-PASMCs, which still have an autoregulatory system in response to exogenous ET1 and/or aldosterone. The relatively low penetrance of PAH within families supports a 'two-hit' hypothesis in which the vascular abnorm- 
alities characteristic of idiopathic $\mathrm{PAH}$ are triggered by accumulation of genetic and/or environmental factors, including upregulation of vasoconstrictive hormones. The combination of increased endothelial injury associated with ET1 production and impaired suppression of PASMC proliferation, partly controlled by BMPs, could be critical for the cellular pathogenesis of PAH. However, there is still a case limitation in our present study, and the accumulation of basic experimental data derived from human samples would be absolutely necessary to elucidate the cellular mechanism leading to the development of idiopathic PAH and the characterization of the molecular basis of differential mechanisms of idiopathic and secondary PAH. The present findings may also permit further understanding of the molecular pathogenesis of $\mathrm{PAH}$ and novel therapeutic prospects to control ET1- and aldosterone-induced activation of MAPK for the prevention of excessive mitosis of PASMCs.

\section{CONFLICT OF INTEREST}

The authors declare no conflict of interest.

\section{ACKNOWLEDGEMENTS}

We thank Dr R Kelly Moore for helpful discussion and critical reading of the manuscript. This work was supported in part by Grants-in-Aid for Scientific Research, the Japan Research Promotion Society for Cardiovascular Diseases, the Japan Foundation of Cardiovascular Research, The Naito Foundation and the Kanae Foundation for Life and Socio-Medical Science.

1 Rubin LJ. Primary pulmonary hypertension. N Engl J Med 1997; 336: 111-117.

2 Palevsky HI, Schloo B, Pietra GG, Weber KT, Janicki JS, Rubin E, Fishman AP. Primary pulmonary hypertesion: vascular structure, morphometry, and responsiveness to vasodilator agents. Circulation 1989; 80: 1207-1221.

3 Wilkins MR, Gibbs JS, Shovlin CL. A gene for primary pulmonary hypertension. Lancet 2000; 356: 1207-1208.

4 Nichols WC, Koller DL, Slovis B, Foroud T, Terry VH, Arnold ND, Siemieniak DR, Wheeler L, Phillips III JA, Newman JH, Conneally PM, Ginsburg D, Loyd JE. Localization of the gene for familial primary pulmonary hypertension to chromosome $2 q 31-32$. Nat Genet 1997; 15: 277-280.

5 Deng Z, Morse JH, Slager SL, Cuervo N, Moore KJ, Venetos G, Kalachikov S, Cayanis E, Fischer SG, Barst RJ, Hodge SE, Knowles JA. Familial primary pulmonary hypertension (gene $\mathrm{PPH} 1$ ) is caused by mutations in the bone morphogenetic protein receptor-II gene. Am J Hum Genet 2000; 67: 737-744.

6 Lane KB, Machado RD, Pauciulo MW, Thomson JR, Phillips III JA, Loyd JE, Nichols WC, Trembath RC. Heterozygous germline mutations in BMPR2, encoding a TGF-beta receptor, cause familial primary pulmonary hypertension. The International PPH Consortium. Nat Genet 2000; 26: 81-84.

7 Thomson JR, Machado RD, Pauciulo MW, Morgan NV, Humbert M, Elliott GC, Ward K, Yacoub M, Mikhail G, Rogers P, Newman J, Wheeler L, Higenbottam T, Gibbs JS, Egan J, Crozier A, Peacock A, Allcock R, Corris P, Loyd JE, Trembath RC, Nichols WC. Sporadic primary pulmonary hypertension is associated with germline mutations of the gene encoding BMPR-II, a receptor member of the TGF-beta family. J Med Genet 2000; 37: 741-745.

8 Morrell NW, Yang X, Upton PD, Jourdan KB, Morgan N, Sheares KK, Trembath RC. Altered growth responses of pulmonary artery smooth muscle cells from patients with primary pulmonary hypertension to transforming growth factor-beta(1) and bone morphogenetic proteins. Circulation 2001; 104: 790-795.

9 Rudarakanchana N, Flanagan JA, Chen H, Upton PD, Machado R, Patel D, Trembath RC, Morrell NW. Functional analysis of bone morphogenetic protein type II receptor mutations underlying primary pulmonary hypertension. Hum Mol Genet 2002; 11 : 1517-1525.

10 Runo JR, Loyd JE. Primary pulmonary hypertension. Lancet 2003; 361: 1533-1544.

11 Giaid A, Yanagisawa M, Langleben D, Michel RP, Levy R, Shennib H, Kimura S, Masaki T, Duguid WP, Stewart DJ. Expression of endothelin-1 in the lungs of patients with pulmonary hypertension. N Engl J Med 1993; 328: 1732-1739.

12 Jeffery TK, Morrell NW. Molecular and cellular basis of pulmonary vascular remodeling in pulmonary hypertension. Prog Cardiovasc Dis 2002; 45: 173-202.

13 Christman BW, McPherson CD, Newman JH, King GA, Bernard GR, Groves BM, Loyd $\mathrm{JE}$. An imbalance between the excretion of thromboxane and prostacyclin metabolites in pulmonary hypertension. N Engl J Med 1992; 327: 70-75.

14 Giaid A. Nitric oxide and endothelin-1 in pulmonary hypertension. Chest 1998; 114: 208S-212S.
15 Ambalavanan N, Bulger A, Murphy-Ullrich J, Oparil S, Chen YF. Endothelin-A receptor blockade prevents and partially reverses neonatal hypoxic pulmonary vascular remodeling. Pediatr Res 2005; 57: 631-636.

16 Rosenberg AA, Kennaugh J, Koppenhafer SL, Loomis M, Chatfield BA, Abman SH. Elevated immunoreactive endothelin-1 levels in newborn infants with persistent pulmonary hypertension. J Pediatr 1993; 123: 109-114.

17 Kunichika N, Landsberg JW, Yu Y, Kunichika H, Thistlethwaite PA, Rubin LJ, Yuan JX. Bosentan inhibits transient receptor potential channel expression in pulmonary vascular myocytes. Am J Respir Crit Care Med 2004; 170: 1101-1107.

18 Davie N, Haleen SJ, Upton PD, Polak JM, Yacoub MH, Morrell NW, Wharton J. ET(A) and $E T(B)$ receptors modulate the proliferation of human pulmonary artery smooth muscle cells. Am J Respir Crit Care Med 2002; 165: 398-405.

19 Abraham WT, Raynolds MV, Badesch DB, Wynne KM, Groves BM, Roden RL, Robertson $A D$, Lowes BD, Zisman LS, Voelkel NF, Bristow MR, Perryman MB. Angiotensinconverting enzyme DD genotype in patients with primary pulmonary hypertension: increased frequency and association with preserved haemodynamics. J Renin Angiotensin Aldosterone Syst 2003; 4: 27-30.

20 Orte C, Polak JM, Haworth SG, Yacoub MH, Morrell NW. Expression of pulmonary vascular angiotensin-converting enzyme in primary and secondary plexiform pulmonary hypertension. J Pathol 2000; 192: 379-384.

21 Okada K, Bernstein ML, Zhang W, Schuster DP, Botney MD. Angiotensin-converting enzyme inhibition delays pulmonary vascular neointimal formation. Am J Respir Crit Care Med 1998; 158: 939-950.

22 Chung WK, Deng L, Carroll JS, Mallory N, Diamond B, Rosenzweig EB, Barst RJ, Morse $\mathrm{JH}$. Polymorphism in the angiotensin II type 1 receptor (AGTR1) is associated with age at diagnosis in pulmonary arterial hypertension. J Heart Lung Transplant 2009; 28: 373-379.

23 Kouchi H, Nakamura K, Fushimi K, Sakaguchi M, Miyazaki M, Ohe T, Namba M. Manumycin A, inhibitor of ras farnesyltransferase, inhibits proliferation and migration of rat vascular smooth muscle cells. Biochem Biophys Res Commun 1999; 264: 915-920.

24 Ogawa A, Nakamura K, Matsubara H, Fujio H, Ikeda T, Kobayashi K, Miyazaki I, Asanuma M, Miyaji K, Miura D, Kusano KF, Date H, Ohe T. Prednisolone inhibits proliferation of cultured pulmonary artery smooth muscle cells of patients with idiopathic pulmonary arterial hypertension. Circulation 2005; 112: 1806-1812.

25 Takeda M, Otsuka F, Suzuki J, Kishida M, Ogura T, Tamiya T, Makino H. Involvement of activin/BMP system in development of human pituitary gonadotropinomas and nonfunctioning adenomas. Biochem Biophys Res Commun 2003; 306: 812-818.

26 Takeda M, Otsuka F, Nakamura K, Inagaki K, Suzuki J, Miura D, Fujio H, Matsubara H, Date $\mathrm{H}$, Ohe T, Makino $\mathrm{H}$. Characterization of the bone morphogenetic protein (BMP) system in human pulmonary arterial smooth muscle cells isolated from a sporadic case of primary pulmonary hypertension: roles of BMP type IB receptor (activin receptor-like kinase-6) in the mitotic action. Endocrinology 2004; 145: 4344-4354.

27 Von Bubnoff A, Cho KWY. Intracellular BMP signaling regulation in vertebrates: pathway or network? Dev Biol 2001; 239: 1-14.

28 Kourembanas S, Marsden PA, McQuillan LP, Faller DV. Hypoxia induces endothelin gene expression and secretion in cultured human endothelium. J Clin Invest 1991; 88: 1054-1057.

29 Wort SJ, Woods M, Warner TD, Evans TW, Mitchell JA. Endogenously released endothelin-1 from human pulmonary artery smooth muscle promotes cellular proliferation: relevance to pathogenesis of pulmonary hypertension and vascular remodeling. Am J Respir Cell Mol Biol 2001; 25: 104-110.

30 Channick RN, Simonneau G, Sitbon O, Robbins IM, Frost A, Tapson VF, Badesch DB, Roux S, Rainisio M, Bodin F, Rubin LJ. Effects of the dual endothelin-receptor antagonist bosentan in patients with pulmonary hypertension: a randomised placebocontrolled study. Lancet 2001; 358: 1119-1123.

31 Shichiri M, Kato H, Marumo F, Hirata Y. Endothelin-1 as an autocrine/paracrine apoptosis survival factor for endothelial cells. Hypertension 1997; 30: 1198-1203.

32 Wu-Wong JR, Chiou WJ, Dickinson R, Opgenorth TJ. Endothelin attenuates apoptosis in human smooth muscle cells. Biochem J 1997; 328(Pt 3): 733-737.

33 Remuzzi G, Perico N, Benigni A. New therapeutics that antagonize endothelin: promises and frustrations. Nat Rev Drug Discov 2002; 1: 986-1001.

34 Massague J. TGF-beta signal transduction. Annu Rev Biochem 1998; 67: 753-791.

35 Miyazono K, Kusanagi K, Inoue H. Divergence and convergence of TGF-beta/BMP signaling. J Cell Physiol 2001; 187: 265-276.

36 Aoki H, Fujii M, Imamura T, Yagi K, Takehara K, Kato M, Miyazono K. Synergistic effects of different bone morphogenetic protein type I receptors on alkaline phosphatase induction. J Cell Sci 2001; 114: 1483-1489.

37 Barst RJ, Langleben D, Badesch D, Frost A, Lawrence EC, Shapiro S, Naeije R, Galie N. Treatment of pulmonary arterial hypertension with the selective endothelin-A receptor antagonist sitaxsentan. J Am Coll Cardiol 2006; 47: 2049-2056.

38 Rubin LJ, Badesch DB, Barst RJ, Galie N, Black CM, Keogh A, Pulido T, Frost A, Roux S, Leconte I, Landzberg M, Simonneau G. Bosentan therapy for pulmonary arterial hypertension. N Engl J Med 2002; 346: 896-903.

39 Star GP, Giovinazzo M, Langleben D. Effects of bone morphogenic proteins and transforming growth factor-beta on in-vitro production of endothelin-1 by human pulmonary microvascular endothelial cells. Vascul Pharmacol 2009; 50: 45-50.

40 Funder JW, Pearce PT, Smith R, Smith Al. Mineralocorticoid action: target tissue specificity is enzyme, not receptor, mediated. Science 1988; 242: 583-585.

41 Edwards CR, Stewart PM, Burt D, Brett L, Mclntyre MA, Sutanto WS, de Kloet ER, Monder C. Localisation of 11 beta-hydroxysteroid dehydrogenase-tissue specific protector of the mineralocorticoid receptor. Lancet 1988; 2: 986-989.

42 Funder JW. The nongenomic actions of aldosterone. Endocr Rev 2005; 26: 313-321. 
43 Nishihara A, Watabe T, Imamura T, Miyazono K. Functional heterogeneity of bone morphogenetic protein receptor-II mutants found in patients with primary pulmonary hypertension. Mol Biol Cell 2002; 13: 3055-3063.

44 Yamaguchi K, Shirakabe K, Shibuya H, Irie K, Oishi I, Ueno N, Taniguchi T, Nishida E, Matsumoto K. Identification of a member of the MAPKKK family as a potential mediator of TGF- $\beta$ signal transduction. Science 1995; 270: 2008-2011.

45 Yamaguchi K, Nagai S, Ninomiya-Tsuji J, Nishita M, Tamai K, Irie K, Ueno N, Nishida E, Shibuya H, Matsumoto K. XIAP, a cellular member of the inhibitor of apoptosis protein family, links the receptors to TAB1-TAK1 in the BMP signaling pathway. EMBO J 1999; 18: 179-187.

46 Nakamura K, Shirai T, Morishita S, Uchida S, Saeki-Miura K, Makishima F. p38 Mitogen-activated protein kinase functionally contributes to chondrogenesis induced by growth/differentiation factor-5 in ATDC5 cells. Exp Cell Res 1999; 250: 351-363.

47 Piek E, Heldin $\mathrm{CH}$, Ten Dijke P. Specificity, diversity, and regulation in TGF- $\beta$ superfamily signaling. FASEB J 1999; 13: 2105-2124.

48 Moore RK, Otsuka F, Shimasaki S. Molecular basis of bone morphogenetic protein-15 signaling in granulosa cells. J Biol Chem 2003; 278: 304-310. 